\title{
I Iarmonizing the Socioeconomic Integration Conditions for Asylum Seekers Through EU Multilevel Financial Coordination
}

\author{
Laura GÓNEZ URQU IJO
}

\begin{abstract}
1bstracl: This analysis examines if enhanced multilevel coordination of financial efforts can contribute to the Europeanization of conditions of integration for refugees, reducing the current lack of cohesion of an EU answer. The paper focuses on possible improvements in this scope through three EU instruments: the reform of the Common European Asy lum System, the EU budgetary funds, and the European Semester.
\end{abstract}

Kevwords: asylum seekers, European I nion, fiscal policy, multilevel coordination.

\section{(1) IXTROD)UCTIO)}

The premise of the present paper is a lack of cohesion in the current response of the EU to the arrival of asylum claimants due to two reasons. On one hand, the inefficiency of the Dublin system' has led to an overflow of asylum seekers into the border-states and an unfair distribution of economic burden among the members of the EU.2 On the other hand, the heterogeneity of social protection systems offered by member states implies divergent conditions for the socioeconomic integration of asylum seekers; ${ }^{3}$ this variety of policies leads to 'asylum shopping', where the applicant for international protection seeks the

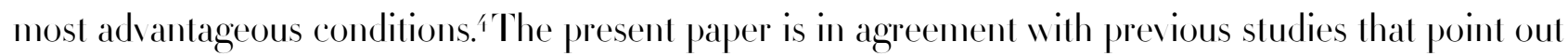
how solidarity, which according to Article 80 of the Treaty of Funclioning of the European Union should govern the EU asylum policy, has failed in the present situation. ${ }^{5}$

ar Irlicle published on .31 December 2org

Associate Professor of Economics of the European U nion, Jean Monnet Chair on Economic and Legal Integration for People, University of Deusto. This Chapter was written within the context of the research project 'The European Union's policies on asy lum: confluences between the internal and the external dimensions' (DER-2017-82/66-R), funded by the Spanish Ministry of Economy and Competitiveness and FEDER, well as the Jean Monnet Chair EU Economic and Legal Integration for People, EAC/ $\mathrm{AO}_{3} 2016(2017-2020)$.

' Council Regulation 6o/ 2013 , O.J $203 \mathrm{~L}_{1} 80 / 56$. See also: M. Di Filippo, The allocation of competence in asslum procedures under EU law: The need to take the Dublin bull by the horns', „9 Revisla de Derecho Comunilario Europeo (2018) 価9.

2 Comparative data by vear and country can be observed in European Parliament data on refugees arriving to the EU; Communication from the Commission to the European Parliament and the Council: Progress report on the Implementation of the European Agenda on Migration, COM(2019) 126.

3 C. Dustman et al., 'On the economics and politics of refugee migration', CEPR, CESifo, Sciences Po, 2017, Economic Policy, July 2017, 2017.

i K. Brenke, 'Distribution of refugees Very Uneven among EU Member States- Even When Accounting for Economic Strength and Total Population', 5 (39) D/II Berlin, German Institule for Economic Research (2015) $5^{11-523}$.

5 J. Abrisheta U riarte, 'La reubicación de los refugiados: un déficit de solidaridady una brecha en la Unión Europea.

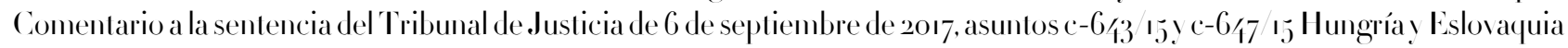

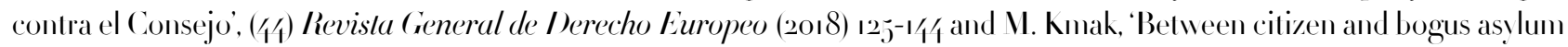


It is noteworthy that the diversity in the conditions provided by member states to refugees depends on their fiscal conditions with respect to their public spending. Integration policy costs are incurred parallel to the efforts that many national governments make to meet their budgetary balance objectives. In this regard, the International Monetary Fund calls attention to the fact that the economic impact of refugees' inflows differs by country according to the available social protection systems. These differences cause a lack of cohesion between member states and misgivings in a section of the public about the economic impact it can have on the social system that guarantees their well-being. Thus, the possible introduction of an additional European support tool to national governments to correct these imbalances has been analysed.

Further, we assess if enhanced multilevel coordination of financial efforts can contribute to the Europeanization of conditions of integration for refugees. We focus on possible improvements in this scope through three EU instruments: the reform of the Common European Asylum Sy stem (CE AS), the EU budgetary funds, and the European Semester.

(B) TIIE F IILU REOF TIIECOMMON EU ROPE I ISILU M SISTEM REFORM TO ACIIENE I GRE UTER IIOMOGE NEITY OF \ ITION IL RECEPTION CONDITIO \S

As noted below, fiscal discipline poses a problem for public funds to respond to the economic challenges of integrating asylum seekers (such as the provision of social services and access to employment). ${ }^{6}$ As pointed by Trauner ${ }^{7}$, these constraints, which have become particularly strict after the 2008 crisis, have exacerbated the deficiencies of the CE IS such as the lack of comparability of the asylum standards of member states. On one hand, some governments find major difficulties to sustain the functioning of their asylum procedures. On the other hand, the weakness of reception conditions is a political choice for those states under fiscal pressure, when a government decides to spend more on issues of such as pensions rather than on receiving international protection claimants. Therefore, some states appeal to their fiscal difficulties to avoid a rise in the level of reception conditions. The non-achievement of the objective of ensuring similar living standards for refugees in all member states contained in the so-called Reception Conditions Directive is evident. ${ }^{8}$

Assuming the failure of the current system to achieve the objectives stated by the European Migration

seeker: management of migration in the EU through the technology of morality', Social Identities, 2015, No 4, 395-409; A. Mangas, 'Protección internacional y europea ante las afluencias masivas de refugiados' 75 Economía Exterior (2015-2016) 39$4^{6}$ and S. Morgades-Gil, 'Forced Migration Management and the Right to Access to an Asvlum Procedure in the Area of Freedom, Security and Justice: Ituman Rights Between Responsibility and Solidarity, i Freedom, Security de Justice: European Legal Studies (2017) 126-1/46.

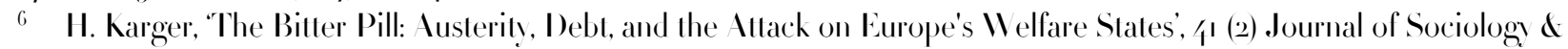
Social Welfare (201/) 33-53; W. Semmler, 'The Macroeconomics of Austerity in the European Union', 8o (3) Social research (2013) $883-91$.

7 F. Trauner, 'Asylum policy: the EU's 'crises' and the looming policy regime failure', $3^{8}$ (3) Journal of European Integration (2016) $33^{11-32}$, at 312 (doi:10.1080 07036337.2016.11/40756).

$8 \quad$ Direclive $201333 \mathrm{UE}, 0 . \mathrm{J}_{2013} \mathrm{~L}_{80} \mathrm{j}_{5} 6$. 
Agenda ${ }^{9}$, we focus on the package to reform the CE IS, as a whole, presented by the European Commission in 2016, which is still pending. "'The proposal for the reform of the Reception Conditions Directiven keeps the previously expressed aim of ensuring access of international protection claimants to living and social services standards. A remarkable novelty in this proposal is the reduction of the maximum time to gain access to the labor market to six months from the beginning of the international protection application. Despite this, the reform does not prevent asylum shopping as national governments can always offer better conditions than those required by the Directive. In fact, some of the most pertinent issues in achieving a harmonization of conditions are exceeding the scope of the EU legal framework; although the Directive seeks to guarantee similar reception conditions, the development of policies and the implementation of programs related to integration (health, education, participation in the labor market, etc.) are exempt from control.'2

On the other hand, the Proposal for a Regulation to establish a stable resettlement framework in the European Union'3 ${ }^{13}$ loes not provide for a mandatory distribution key according to the criteria for economic and social integration. Nor does this integration occur in the Proposal for a Regulation establishing the mechanisms for determining a member state responsible for examining an application for international protection.' 'This proposal maintains a corrective allocation mechanism in cases where that member state faces a disproportionate number of applications for international protection, which is modulated by the weight of the GDP and population of each country. There are no other requirements on the states capacity to receive refugees from the point of view of social policy or labour integration. In summary, the CEAS reform does not seem to contribute to the implementation of socioeconomic conditions of integration by national governments in a harmonized way.

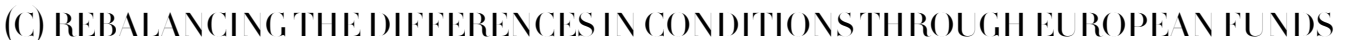

In view of the cohesion deficit raised, we examine the potential improvement through the financial tools that correct the imbalances in the EU. The main instrument acting in this area has been the Asylum,

9 European Commission, Communication from the Commission to the European Parliament, the Council, the European Economic and Social Commillee and the Commillee of the Regions. 1 European Agenda on Migralion, 13 May $2015, \mathrm{COM}$ $(2015) 2$ o.

10 European Commission, Communication from the Commission to the European Partiament, the Council. Towards a reform of the Common European 1svlum Svslem and enhancing legal avenues to Europe, 6 April 2016, COM (2016) 197 final.

" European Commission, Proposal for a Directive of the European Parliament and of the Council laving down Slandards for the Reception of Ipplicants for Inlernalional Prolection (Recast), 13. Julv 2016, COM (2016) 465 linal.

12 D. Bräuninger, Reform of the common European asvlum syslem: A difficult underlaking, (Deutsche Bank Research, Frankfurt am Main, 2018), at 8-ı.

13 European Commission, Proposal for Regulation of the European Parliament and of the Council eslablishing a I nion Resellement Framework: and amending Regulation (EU) $\mathrm{No}_{5}{ }_{16} 6{ }_{201}$ of the European Parliament and the Council, $\mathrm{s}_{3}$ Juls $2016, \mathrm{COM}(2016)$ 468 final.

'1 European Commission, Proposal for a Regulation of the European Parliament and of the Council Establishing the Crileria and Vechanisms for Delermining the Vember Stale Responsible for Examining an Ipplication for International Prolection Lodged in one of the Vember Slales by a Third-country Valional or a Slaleless Person (recasl), 4 May 2016, CO I (2016) 270 linal. 
Migration and Integration Fund ( MIF) that has channelled the compensations that member states can obtain for resettled refugees as well as funding dedicated to the socioeconomic integration of asylum seekers. ${ }^{5}$ It is important to note that the new Financial Framework $2021-2027$ includes a new Asylum and Migration Fund ( MTF) ${ }^{16}$ in place of the A MIF. We call attention to the fact that the word "integration" is not present in the new denomination, although financial support for this area is expected in its initial phase. In addition, the AMIF is designed to respond to reception needs in the short and medium term but is insufficient to respond to long-term measures of social integration; these must be supported through the deployment of other funds, ${ }^{17}$ such as the European Social Fund (ESF), the Fund for European Aid to the Most Deprived (FE DD), and the European Regional Development Fund (ERDF) ${ }^{18}$. A new tool supporting the integration of refugees is foreseen for the $2021-2027$ period: the European Social Fund $(\mathrm{ESF}+)^{.9}$

Despite this proliferation of funds, none of them include any specific assignation for asylum seekers. This issue also prevents the assessment of the quantitative impact of all the aforementioned funds for the socioeconomic integration of people demanding international protection. The European Commissionzo recognizes their positive contribution on actions related to inclusion, education, and access to the labor market for people from third countries. However, data on its impact are global or apply to migrants in general. ${ }^{21}$

Subsidiarity in social policy leaves the extent of the use of funds for this purpose in the hands of national governments with no obligation. ${ }^{22}$ In addition, the indicated proliferation of funds generates the image of many possible resources, without clear mechanisms available to take advantage of synergies among them and avoid duplication or uncovered areas. In this sense, it is important to note that the European Commission urges governments to reinforce their integration policies and to use the European funds available for it; complementarity and synergies between national and European strategies are enhanced, but no enforcement for this purpose exists. The European Commission underlines that

5.5 Regulation (EU) No $5^{16}$ 201/4 of the European Parliament and of the Council of a 6 April 201/4 establishing the Asvlum, Migration and Integration Fund, amending Council Decision $2008 / 3^{81}$ EC and repealing Decisions $V_{0} 573$ 2007 EC and Vo $57.5 / 2007$ EC of the European Parliament and of the Council and Council Decision $2007 / 435$ EC, O.J 2013 L $150 / 57$.

16 European Commission, Proposal for a Regulation of the European Parliament and of the Council eslablishing the 1.svlum and Wigralion Fund, 12 June 2018, COM (2018) 47 final.

${ }_{17}$ Eurofound, Approaches to the labour markel inlegration of refugees and asylum seekers, Publicalions Office of the European I nion, (Eurofound, Luxembourg, 2016).

is European Commission, Toolkit on the use of EU funds for the inlegration of people with a migrant back:ground, Directorate-General for Regional and U rban Policy Inclusive Growth, U rban and Territorial Development Unit 2018$)$ at II-I2.

19 European Commission, Proposal for a Regulation of the European Parliament and of the Council on the European Social Fund Plus (ESF), 30 Mav 2018, COM (2018) $3^{82}$ final.

20 European Commission, Communication from the Commission to the European Parliament, the Council, the Commillee of the Regions Economic and Social Council, Action Plan on the inlegration of third country nationals, 7 July 2016, CO M (2016) 377 final.

${ }^{21}$ European Commission, Employment and Social developments in Europe 2016 (European Commission, Brussels, 2016) at III.

${ }_{22}$ Eurofound, supra n 17 . 
member states should consider the multilevel governance approach at regional, national, and European levels. ${ }^{23}$

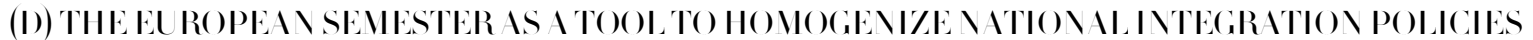

With regard to the multilevel perspective, we evaluate how the coordination of national policies can be performed to achieve a better integration of asylum seekers. We find that, after the failure of the Open Method of Coordination to achieve social objectives ${ }^{24}$, the European Semester procedure ${ }^{23}$ is the key element called to carry out that multilevel coordination. Despite its initial function to reinforee the fiscal pillar of the new economic governance, it has progressively incorporated social objectives in the various slages of its procedure aiming to synchronize national policies. ${ }^{26}$

To assess the weight of refugees' integration in the European Semester mechanisms, we first examine the Annual Growth Surveys, as they are the basis for the endorsement of annual EU and national level priorities by the European Council and the European Commission. This analysis shows that the aforementioned integration of refugees is present among the key challenges faced by the EU. Thus, the European Commission highlights the budgetary impact of the exceptional inflow of refugees when provoking possible temporary deviations from the Stability and Growth Pact requirements. At the same time, it states that this phenomenon can have a positive economic impact on growth, provided the right policies to enhance the integration process (with special mention to removing obstacles to refugee's access to the labor market). ${ }^{27}$ It is significant that, in the Annual Growth Survey 2018,28 this question is linked to social integration support (such as health childcare or housing) as a means that improves the host country's growh prospects and will enable the EU to capitalize on the potential of refugees and their families. However, the most recent Annual Growth Survey (20r9) points out that, while some member states took further measures to promote the integration of refugees into the labour market, systematic

23 European Commission, Toolkil on the use of EU, supra n. 18, at I1-12. European Commission, European Struclural and Investment Funds Guidance for Vember Slates on the use of European Struclural and Investment Funds in lackling educational and spatial segregation, (published in 201/, accessed 20 October 2019). European Commission, European Structural and Investment Funds 'Guidance for Member States on the transition from institutional to community-based care (published in 201\%, accessed in October 2019).

¿1 II. Frazer, and E. Marlier, 'Strengthening social inclusion in the Europe 2020 strategy by learning from the past?’, E. Marlier and D. \atali (eds.) with R. V and dam, Europe 2020: Towards a more social El ?, (Brussels: PIE Peler Lang, Brussels, 2010).

25 EU Regulation $1176 / 2011$.

26. J. Zeillin and B. Vanhercke, 'Socializing the European Semester?', Economic Governance and Social Policy Coordination in Europe 2020 , SIEPS, 7, 201/.

${ }^{27}$ European Commission, Communication from the Commission to the European Parliament, the Council, the European Central Bank, the European Economic and Social Commillee, the Commillee of the Regions and the European Investment Bank: Innual Growth Survey 2016 Strenglhening the recovery and fostering convergence, COM (2015) 690 linal.

${ }^{28}$ European Commission, Communication from the Commission to the European Parliament, the Council, the European Central Bank, the European Economic and Social Commillee, the Commillee of the Regions and the European Investment Bank, Innual Growth Survey 20I8, 22 Jovember 2017, COM (2017) 6go final, at so. 
approaches are lacking. ${ }^{29}$

Following the European Semester cycle, we examine the Country Specific Recommendations (CSRs) provided annually to national governments to achieve the priorities signalled. The initial examination of these recommendations reveals that the integration of refugees has little prominence among the objectives that are prioritized. Recommendations are too vague and refer to persons with migrant background, not to refugees in particular. Since the outset of the European Semester from $20 n$ to 2019, only rg CSRs address this question (13 referring to employment, $ّ$ to education and s to developing comprehensive social inclusion strategies). Only eight national governments receive CSRs in this scope (Austria, Belgium, Denmark, Finland, France, Vetherlands, Luxembourg and Sweden). This fact contrasts with the importance and generalization of those recommendations related to fiscal discipline and is coherent with studies evidencing that social objectives are perceived as less important or less accessible to EU effective action. ${ }^{30}$ While CSRs regarding fiscal policy contain numbered objectives, many other policy recommendations (here, we include those related to refugees' integration) do not present either numeric targets to be attained or sanctions in the case of non-achievement. Consequently, the answers given by states are also vague and the follow up of its observance presents important limitations.

\section{(E) COXCLLSIO)}

Through the analysis carried out, we have ratified the importance of EU fiscal constraints on national budgets in the lack of homogeneity of socioeconomic support for asylum seekers' integration. Moreover, this question is frequently used as an alibi, hiding a political choice for social policies that benefit nationals.

In our view, the proposals for the reform of the European Common Asylum System do not contribute to solving this deficiency, as social integration and public capacity for integration are almost missing. For its part, the diverse European funds that potentially contribute to this scope are not duly focused to this aim, with defined targets or assigned pereentages. Jewly, the use of these resources for these purposes depends on the national government's decision.

Is a consequence, understanding that subsidiarity in social policy is defining the nonEuropeanization of these conditions, we highlight the importance of multilevel financial coordination of policies in this area. We observe that the European Semester is underused, and we point out the potentiality of this instrument to coordinate national fiscal efforts in this domain. Notably, this includes the socioeconomic integration of refugees in the CSRs with precise targets and monitoring of national governments performance.

\footnotetext{
${ }^{29}$ European Commission, Irafi Joint Employment Report from the Commission and the Council accompanving the Communicalion from the Commission on the Annual Growth Survey 2019, 21 Vovember 2018 COM (2018) 761 final, al 77-79.

$3^{30}$ P. Claevs et al., The European Dimension in the National Reform Programs and the Stability and Convergence Programs, Directorale-General for the Internal Policies of the U nion (European Parliament, Brussels, 2013); S. De Finance, I 'Iraffic-light approach' to the implemenlation of the 2011 and 2012 Country Specific Recommendations (CSRs), (Directorate-General for the Internal Policies of the Union. European Parliament, Brussels, 2013); D). Gros and C. Alcidi, Fiscal and macro-structural challenges and policy recommendalions for the Euro Area and ils Vember Slales under the 201/, Semesler Cycle (Directorate General for Internal Policies. Economic Governance Support Unit, Brussels, 201/).
} 